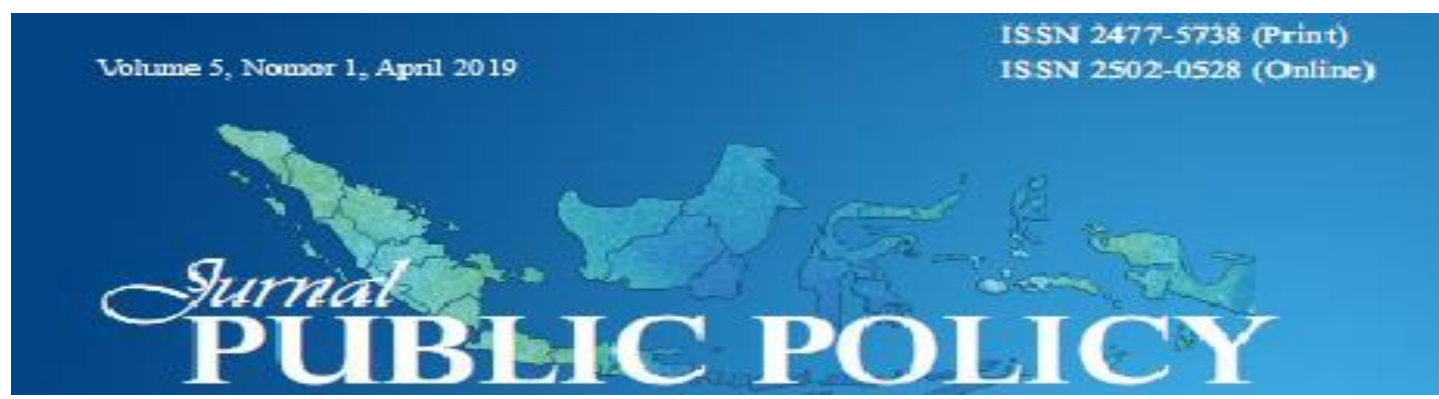

Journal homepage: http//:jurnal.utu.ac.id/jppolicy

\title{
PREMAN RECEH (PENGARUH MANTAN KOMBATAN GAM TERHADAP POLITIK DI TANAH RENCONG ACEH DI ERA OTSUS)
}

\author{
Sulfia Andika ${ }^{1}$, Egi Saputra ${ }^{2}$, Dista Setya Ningsih ${ }^{3}$ Sarabila $^{4}$ Alimas Jonsa ${ }^{5}$ \\ 1,2,3,4 Mahasiswa Ilmu Administrasi Negara Fakultas Ilmu Sosial dan Ilmu Politik \\ Universitas Teuku Umar \\ andika.zalukhu2324@gmail.com, egisaputrambo@gmail.com, \\ distasetianingsih@gmail.com, sarabillabilla22@gmail.com \\ ${ }^{5}$ Dosen Ilmu Administrasi Negara Fakultas Ilmu Sosial dan Ilmu Politik \\ Universitas Teuku Umar \\ alimasjonsa@gmail.com
}

\begin{abstract}
Aceh as a special autonomous region according to the mandate contained in the Aceh Government Law (UUPA) No. 11 of 2006 which gives authority to Aceh,one of which can form a local party and regional regulations (qanun) themselves. The specificity of Aceh is the result of reconciliation between the Free Aceh Movement (GAM) and the Indonesian Government in an effort to resolve endless conflicts. After a conflict resolution effort is realized, to supervise and participate in carrying out the cousre of the UUPA the GAM ex-combatants are now participating in politics which is a better alternative in seeking justice and the rights of the people of Aceh. Therefore, this study aims to find out how much the influence of former GAM combatants on politics in Aceh and the indicators used to enter the political system in Aceh, especially in the districts of West Aceh and Nagan Raya. The methodology used in this study is the qualitative research methodology, with the descriptive approach expected in this study the results found are, in the form of conclusions and suggestions that can build both for former GAM combatants and for the community in their involvement in political implematation in Aceh.
\end{abstract}

Keyword: Influence, Combatants, Aceh 


\section{PENDAHULUAN}

Gerakan Aceh Merdeka (GAM), merupakan salah satu gerakan yang pernah ada di Aceh yang pernah berseteru dengan Pemerintah Indonesia. yang disebabkan oleh ketidakpuasana rakyat Aceh terhadap kebijakan pemerintah Indonesia yang Sentralisasi dan diskriminatif. Konflik yang terjadi antara Gerakan Aceh Merdeka dengan Indonesia berlangsung dalam jangka waktu yang cukup lama yang menelan banyak korban jiwa dan berbagai pelanggaran-pelanggaran Hak Asasi Manusia yang hingga saat ini tidak ada penyelesaian yang jelas akan hal tersebut.

Akhirnya pada awal era Reformasi dimulai, berbagai upaya-upaya untuk menghentikan perseteruan antara pemerintah Indonesia dengan Gerakan Aceh Merdeka semakin serius dilakukan yang dimana pada tahun 2004 terjadi bencana dahsyat gempa bumi yang diiringi gelombang Tsunami yang menelan banyak korban jiwa serta kerusakan infrastruktur yang parah dan lumpuhnya berbagai kegiatan dan aktifitas masyarakat. Secara tidak langsung bencana dahsyat ini juga menjadi salah satu faktor besar yang mempengaruhi jalannya proses perdamaian antara GAM dengan Pemerintahan Indonesia yang pada akhirnya dapat tercapai dengan berhasil dicapainya kesepakatan damai di Vantaa, Helsinki, Finlandia ditandai dengan Penandatanganan Nota Kesepakatan (MoU) damai yang dilangsungkan pada 15 Agustus 2005 di Helsinki, Finlandia yang difasilitasi oleh Crisis Management Initiative (CMI) dimana salah satu syarat kesepakatan tersebut yaitu diberikannya kekhususan pada Aceh yang kemudian disebut Otonomi Khusus sesuai dengan UU No. 11 Tahun 2006 Tentang Pemerintahan Aceh.

Menurut Peter Harris dan Ben Reilly, Otonomi Khusus yaitu wilayah-wilayah tertentu di dalam suatu negara yang diberikan kewenangan khusus yang tidak diberikan kepada wilayah-wilayah lain. Salah satu implementasi dari Otonomi Khusus yang diberikan pada Aceh dapat dilihat dengan berdirinya partai-partai politik lokal di Aceh, yang menjadi salah satu media demokrasi bagi rakyat Aceh untuk ikut serta dalam sistem pemerintahan Indonesia. Hal tersebut juga menjadi salah satu strategi jitu yang di manfaatkan oleh mantan kombatan GAM untuk ikut serta 
mengawal jalannya pemerintahan. Saat ini banyak mantan anggota Gerakan Aceh Merdeka mendominasi keanggotaan dalam partai politik baik lokal maupun nasional yang keberadaannya tidak dapat dielakkan lagi.

Khusus di Kabupaten Aceh Barat dan Nagan Raya yang merupakan dua Kabupaten yang ada di Aceh yang menjadi pusat atau kiblat daerah pantai barat selatan Aceh, keberadaan mantan kombatan Gerakan Aceh Merdeka sangat diperhitungkan dalam perpolitikan Aceh. Para mantan kombatan GAM ini selain dianggap memiliki kemampuan politik yang cukup, mereka juga menjadikan peran mereka dimasa lalu saat melakukan upaya untuk merdeka dari Indonesia sebagai salah satu cara untuk mencari perhatian agar lebih mudah berkecimpung dalam dunia politik. Selain itu, saat ini mereka juga menjadi tokoh-tokoh masyarakat di Aceh yang sangat dihormati dan disegani sehingga mereka. memiliki pengaruh yang cukup besar dalam proses perpolitikan di Aceh terutama di Kabupaten Aceh Barat dan Nagan Raya. Oleh karena itu, penelitian ini dirasa perlu dilakukan untuk mengklasifikasikan serta mendeskripsikan seberapa jauh peran dan pengaruh keberadaan mantan anggota kombatan Gerakan Aceh Merdeka dalam seluruh proses perpolitikan yang ada di Kabupaten Aceh Barat dan Nagan Raya khususnya dan di Aceh secara umum.

\section{KERANGKA KONSEP}

Menurut penelitian yang dilakukan oleh Fajrul Zuhri dan Khairulyadi pada tahun 2017 yang berjudul Reintegrasi Mantan Kombatan Gerakan Aceh Merdeka (GAM) dengan hasil dari penelitian tersebut yakni : pertama, reintegrasi bertujuan untuk membangun kembali norma-norma, nilai-nilai dan struktur sosial ekonomi masyarakat paska terjadianya konflik. Proses reintegrasi mantan kombatan GAM terus dilakukan sampai para mantan kombatan telah benar-benar kembali kepada masyarakat walaupun sampai saat ini integrasi sosial para mantan kombatan GAM masih menjadi masalah seperti integrasi ideologis. Kedua, respon masyarakat kepada para kombatan GAM dan tahanan politik yang kembali lebih dahulu ke gampong tidak menimbulkan masalah. Sebagian besar dari GAM yang aktif $(80 \%)$ kembali ke desa pada dua bulan setelah penandatanganan MoU. Dalam hampir banyak kasus, 
tingkat penerimaan terhadap anggota GAM yang kembali cukup tinggi yaitu $90 \%$ pada bulan-bulan selanjutnya.

Penelitian selanjutnya yang menjadi referensi penulis yaitu oleh Edwin Yustian Driyartana pada tahun 2010 yang berjudul Kedudukan Partai Politik Lokal Di Nanggroe Aceh Darussalam Ditinjau Dari Asas Demokrasi dengan hasil dari penelitian tersebut yakni : Pertama, latar belakang partai politik lokal di Aceh dan implikasi partai politik lokal dalam sistem kepartaian Indonesia ditinjau dari asas demokrasi yang muncul ditandai dengan disepakatinya persyaratan dari Gerakan Aceh Merdeka berupa keberadaan partai politik lokal di Aceh oleh pemerintah Republik Indonesia dalam Memorandum Of Understanding (MoU) Helsinki sebagai upaya untuk mengakhiri konflik bersenjata yang berkepanjangan di Aceh. Kedua, kehadiran partai politik lokal dalam sistem kepartaian Indonesia membawa implikasi berupa amandemen pada Undang-Undang Pemerintahan Aceh (UUPA) guna mengakomodasi keberadaan partai politik lokal di Aceh yang berlaku sebagai lex specialis derograt lex generale. Keberadaan partai politik lokal di Aceh juga turut membawa implikasi berupa menurunnya perolehan suara partai politik nasional dalam pemilihan umum lokal yang dilaksanakan pada tahun 2009 di Aceh, dimana Partai Aceh berhasil mendominasi dalam perolehan suara jauh di atas partai politik nasional dan partai politik lokal lainnya, dimana sebagian besar anggota Partai Aceh merupakan mantan kombatan GAM yang banting setir ke sektor perpolitikan Aceh pasca MoU Helsinki di tanda tangani. Oleh karena itu, penting rasanya untuk mengetahui bagaimana kemudian pengaruh mantan kombatan GAM dalam perpolitikan di Aceh di era otonomi khusus ini dalam tatanan kehidupan masyarakat di Aceh yang sedang dalam proses pembanguan berkelanjutan.

\section{Pengertian Pengaruh}

Pengaruh adalah daya yang ada atau timbul dari sesuatu, baik orang maupun benda dan sebagainya yang berkuasa atau yang berkekuatan dan berpengaruh terhadap orang lain (Poerwardaminta:731). 
Menurut Badudu dan Zain (1994 ; 1031), “ pengaruh adalah daya yang menyebabkan sesuatu yang terjadi, sesuatu yang dapat membentuk atau mengubah sesuatu yang lain, dan tunduk atau mengikuti karena kuasa atau kekuatan orang lain". Sedangkan menurut Wiryanto "pengaruh merupakan tokoh formal maupun informal di dalam masyarakat, mempunyai ciri lebih kosmopolitan, inovatif, kompeten, dan aksesibel dibanding pihak yang dipengaruhi”.

\section{Pengertian Politik}

Heywood merumuskan politik secara luas sebagai keseluruhan aktivitas di mana masyarakat membuat, mempertahankan dan membuat amandemen aturanaturan umum di mana mereka hidup. Istilah politik berkembang sedemikian rupa sehingga diserap ke dalam bahasa kita (Indonesia) dengan mempunyai 3 (tiga) arti (WJS Poerwadarminta, 183: 763) yaitu: "segala urusan dan tindakan atau kebijaksanaan, siasat dan sebagainya mengenai pemerintahan sesuatu negara terhadap negara lain, tipu muslihat atau kelicikan, dan juga dipergunakan sebagai nama bagi sebuah disiplin "pengetahuan yaitu ilmu politik". Jadi, menurut paparan di atas maka dapat ditarik kesimpulan bahwa politik ialah berbagai kegiatan dalam suatu sistem politik atau negara yang menyangkut proses penentuan tujuan dari sistem itu, dan bagaimana melaksanakan tujuan-tujuannya.

\section{Teori Pengaruh}

Menurut Badudu dan Zain (1994;1031); pengaruh mencakup beberapa aspek, yaitu :

a. Daya atau komponen pendukung

b. Kemampuan atau skill

c. Kekuatan (Power)

Berikut disajikan bagan alir mengenai pengaruh mantan kombatan GAM terhadap politik di Aceh Barat dan Nagan Raya di Era Otsus yang dapat dilihat pada gambar berikut. 


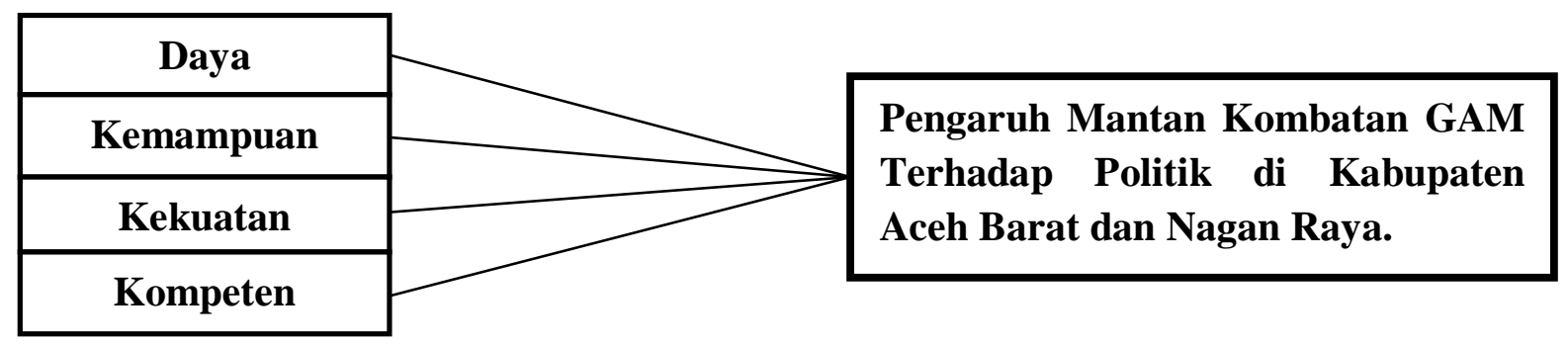

\section{Metode Penelitian}

Tempat dan Waktu Penelitian Penelitian mengenai PREMAN RECEH (Pengaruh Mantan Kombatan GAM Terhadap Politik Di Tanah Rencong Aceh di Era OtSus): Studi Kasus di Kabupaten Aceh Barat dan Nagan Raya ini akan dilakukan selama 3 bulan.

Metode Penelitian Metode penelitian yang digunakan pada penelitian ini adalah metode kualitatif dengan pendekatan deskriptif. Teori yang digunakan menggunakan teori Badudu dan Zain (1994;1031).

Teknik Penentuan Informan Teknik penentuan informan dalam penelitian dengan menentukan informasi kunci yaitu mantan kombatan GAM, partai politik lokal maupun nasional, masyarakat, Anggota Parlemen Kab. Aceh Barat dan Nagan Raya, Bupati Aceh Barat dan Nagan Raya serta Komisi Independen Pemilihan Kabupaten Aceh Barat dan Nagan Raya. Informan yang dipilih dalam penilaian ini adalah: Mantan Kombatan GAM, Partai Politik, KPU/ KIP, Masayarakat, Anggota Parlemen terpilih, Bupati.

Teknik Pengumpulan Data Pengambilan data dapat dilakukan dengan teknik observasi, wawancara dan dokumentasi.

Observasi : Dalam penelitian ini, observasi digunakan untuk mengetahui sejauh mana pengaruh mantan kombatan GAM dalam perpolitikan di Aceh. Peneliti melakukan penelitian dengan pedoman observasi yang telah ditetapkan (Arikunto, 2006). 
Wawancara: Metode wawancara digunakan peneliti untuk mendapatkan informasi-informasi mengenai pengaruh mantan kombatan GAM dalam perpolitikan di Aceh terutama di Kabupaten Aceh Barat dan Nagan Raya.

Dokumentasi: Dokumentasi merupakan suatu teknik pengumpulan data dengan menghimpun dan menganalisis dokumen-dokumen baik dokumen tertulis, gambar maupun dokumen elektronik. Dokumen-dokumen yang dihimpun dipilih sesuai dengan tujuan dan fokus masalah (Sukmadinata, 2005).

\section{Teknik Analisis Data dan Uji Keabsahan Data}

Penelitian ini adalah penelitian deskriptif, dengan lebih banyak bersifat uraian dari hasil wawancara dan studi dokumentasi. Data yang telah diperoleh akan dianalisis secara kualitatif serta diuraikan dalam bentuk deskriptif.

Menurut Patton (Moleong, 2002) analisis data adalah "proses mengatur urutan data, mengorganisasikannya ke dalam suatu pola, kategori dan uraian dasar”. Definisi tersebut memberikan gambaran tentang betapa pentingnya kedudukan analisis data dilihat dari segi tujuan penelitian. Prinsip pokok penelitian kualitatif adalah menemukan teori dari data.

Teknik Analisis data yang digunakan dalam penelitian ini adalah menggunakan langkah langkah seperti yang dikemukakan oleh Burhan Bungin (2001), yaitu sebagai berikut: Pengumpulan Data (Data Collection) Pengumpulan data merupakan bagian integral dari kegiatan analisis data. Kegiatan pengumpulan data pada penelitian ini adalah dengan menggunakan wawancara dan studi dokumentasi.

Reduksi Data (Data Reduction). Reduksi dilakukan sejak pengumpulan data dimulai dengan membuat ringkasan, mengkode, menelusur tema, membuat gugusgugus, menulis memo dan sebagainya dengan maksud menyisihkan data/informasi yang tidak relevan.

Display Data: Display data adalah pendeskripsian sekumpulan informasi tersusun yang memberikan kemungkinan adanya penarikan kesimpulan dan pengambilan 
tindakan. Penyajian data kualitatif disajikan dalam bentuk teks naratif. Penyajiannya juga dapat berbentuk matrik, diagram, tabel dan bagan.

Verifikasi dan Penegasan Kesimpulan (Conclution Drawing and Verification) Merupakan kegiatan akhir dari analisis data. Penarikan kesimpulan berupa kegiatan interpretasi, yaitu menemukan makna data yang telah disajikan.

\section{HASIL DAN PEMBAHASAN}

Hasil dalam penelitian ini di paparkan dengan di dasari dengan data yang di peroleh dari rangkaian penelitian yang dilakukan dengan cara observasi, wawancara dan dokumentasi. Dalam rangkaian penelitian yang dilakukan di Aceh Barat dan Nagan Raya yang menjadi studi kasus dalam penelitian ini terdapat suatu realita dimana mantan kombatan GAM yang ikut serta dalam kompetisi politik ditanah rencong aceh pada era sekarang ini lebih dikenal dan dikaitkan dengan keberadaan partai politik lokal yaitu Partai Aceh. Masyarakat, elit politik maupun akademisi memahami bahwa partai Aceh merupakan partai lokal yang ada di tanah rencong aceh yang asal muasalnya di bentuk oleh para mantan kombatan GAM yang tidak lain dan tidak bukan dijadikan sebagai wadah baru dan menjadi salah satu bentuk atau usaha untuk tetap mengawal jalannya otonomi khusus yang diberikan untuk Aceh serta dengan tujuan untuk tetap berjuang memenuhi hak-hak dan kesejahteraan bagi rakyat aceh. Hal ini menunjukan bahwa GAM yang dulunya dikenal dengan strategi gerilya kini beralih pada strategi politik yang saat ini menjadi salah satu strategi yang paling familiar dan trendi di tengan masyarakat Indonesia umumnya dan Aceh sendiri pada khususnya. Artinya, partai aceh merupakan bentuk usaha yang dilakukan oleh para mantan kombatan GAM untuk memenuhi segala sesuatu yang menjadi hak-hak rakyat aceh sehingga menjadi suatu yang sah bila kita mengatakan mantan kombatan GAM sama dengan Partai Aceh. 


\section{Pengaruh Mantan Kombatan GAM (Partai Aceh) dalam perpolitikan ACEH} (Kabupaten Aceh Barat dan Nagan Raya)

\section{* Aceh Barat}

Kabupaten Aceh Barat yang menjadi salah satu daerah yang memiliki potensi politik yang cukup intens tidak terlepas dari keikutsertaan mantan kombatan GAM (Partai Aceh) dalam kontestasi politik yang ada di Aceh Barat. Baik pada pemilihan legislatif maupun pemilihan kepala daerah, keberadaan Partai Aceh cetusan para mantan kombatan GAM yang ikut serta dalam kontestasi akan selalu menjadi pilihan utama untuk dipertimbangkan oleh masyarakat. Realita ini dapat dilihat dari hasil pemilihan legislatif Aceh Barat tahun 2014 dimana Partai Aceh meraih 5 kursi parlemen bersama dengan Partai Amanat Nasional yang meraih kursi yang sama meski PAN unggul dalam perolehan suara. Namun secara keseluruhan, partai aceh memiliki pengaruh yang besar di masyarakat sehingga mendapatkan 5 kursi di DPRK Aceh Barat dari total 25 kursi yang ada. Pada pemilihan legislatif tahun 2019 di kabupaten Aceh Barat juga menunjukan suatu fakta dimana Partai Aceh memiliki pengaruh yang sangat signifikan dibuktikan dengan perolehan suara tertinggi dan kursi terbanyak yang menjadikan Partai Aceh mendapatkan kursi ketua DPRK untuk lima tahun kedepan.

Hasil yang diperoleh dalam pemilihan kepala daerah pun menunjukan bahwa dalam dua kali pemilihan kepala daerah di Aceh Barat, Partai Aceh selalu ikut dalam kontestasi pemilihan orang nomer satu di Aceh Barat tersebut. Pada pemilihan kepala daerah tahun 2012, sebanyak 13 kandidat berpartisipasi dalam pemilihan kepala daerah yang terjadi dengan dua kali putaran dan Partai Aceh yang mengusung pasangan Teuku Aldiansyah dan Rachmad Fitri HD menang dalam pemilihan Bupati dan Wakil Bupati Kabupaten Aceh Barat. Pada Pemilukada tahun 2017, Partai Aceh juga kembali ikut dalam kontestasi pemilihan Bupati dan Wakil Bupati Aceh Barat yang mengusung Ramli MS dan Banta Puteh sebagai calon yang juga akhirnya dimenangkan oleh pasangan calon usungan dari partai Aceh tersebut. 
Ini menjadi bukti bahwa partai aceh dengan segala visi dan misi yang dicetuskan oleh mantan kombatan GAM memiliki tempat di tengah-tengah masyarakat dalam perpolitikan baik dalam pemilhan kepala daerah maupun dalam pemilihan anggota legislatif di Aceh Barat.

\section{* Nagan Raya}

Untuk wilayah kabupaten Nagan Raya, keberadaan mantan kombatan GAM memiliki pengaruh yang cukup besar. Untuk pemilihan anggota legislatif pada tahun 2014, partai Aceh berada pada urutan kedua perolehan suara yakni sebanyak 6.140 suara $(14,5 \%)$ dan mendapat 3 kursi DPRK Nagan Raya. Perolehan suara dan kursi tersebut masih kalah dari Partai Golkar yang meraih suara sebanyak 11.106 suara (26,2 \%) dan mendapatkan 7 kursi di DPRK Nagan Raya. Meski perolehan suara dan kursi legislatif Partai Aceh masih dibawah partai Golkar, namun keberadaan mantan kombatan GAM yang ikut langsung dalam pemilihan anggota legislatif menjadi salah satu hal yang cukup menarik, dimana mantan kombatan GAM yang berkompetisi memiliki kesan tersendiri di hati masyarakat yang kemudian memiliki daya tarik tersendiri sehingga masyarakat memilihnya. Samsu Ardi, SH yang merupakan mantan Panglima kombatan GAM atau yang lebih dikenal dengan Juragan merupakan salah satu mantan kombatan GAM yang ikut berkompetisi dan mendapat respon yang baik dari masyarakat. Masyarakat Nagan Raya sangat mengenal salah satu mantan kombatan GAM satu ini, apalagi bila kita menyebutkan panggilannya (Juragan), masyarakat Nagan Raya pasti mengetahui dengan baik mantan kombatan GAM yang menjabat Ketua DPRK periode 2014-2019 Kabupaten Nagan Raya ini.

Pada pemilihan anggota legislatif tahun 2019, untuk wilayah Kabupaten Nagan Raya perolehan suara Partai Aceh dipastikan merosot turun dengan hanya ada pada posisi ke empat dengan memperoleh suara sebanyak 10.498. Jumlah tersebut masih di bawah partai lain seperti Partai Sira (11.584), Partai Golkar (11.645) dan Partai Demokrat (26.710). Samsu Ardi, SH yang merupakan anggota partai Aceh 
menjelaskan bahwa, penurunan perolehan suara Partai Aceh disebabkan oleh semakin terbuka dan berkembangnya perpolitikan Aceh yang diiringi dengan gerakan Millenial di tengah-tengah masyarakat yang mempengaruhi pola pikir yang kemudian mengurangi pemahaman masyarakat terhadap keberadaan Partai Aceh yang hakikatnya merupakan partai perjuangan rakyat Aceh yang harusnya di dukung. Meski demikian, pengaruh Partai Aceh dengan peran mantan anggota kombatan GAM dibalik layar setiap kontestasi politik masih sangat besar ditengah masyarakat Nagan Raya dan hal tersebut akan sangat sulit dihilangkan dari kehidupan sosial politik masyarakat Nagan Raya.

Dalam kontestasi pemilihan kepala daerah, Nagan Raya menjadi salah satu daerah dengan kompetisi yang cukup ketat dan tidak terlepas dari keterlibatan Partai Aceh. Pada pemilihan kepala daerah tahun 2012, pasangan calon yang diusung oleh Partai Aceh yakni Zulkarnaini-M. Jamid Idham unggul dengan perolehan suara sebanyak 43.604 suara atau 51,25 \%. Hasil ini menunjukan bahwa pengaruh partai Aceh yang mengusung pasangan calon Bupati dan Wakil Bupati dalam pemilihan kepala daerah Kabupaten Nagan Raya memiliki tempat tersendiri yang sehingga semakin menguatkan posisi Partai lokal satu ini. Kedudukan Partai Aceh dalam perpolitikan di Nagan Raya semakin diperkuat ditandai dengan menangnya pasangan calon nomer urut 05 yakni HM Jamin Idham-Chalid Oesman dalam pemilihan kepala daerah pada tahun 2017. Dalam rapat pleno terbuka rekapitulasi suara oleh KIP Nagan Raya, pasangan calon usungan Partai Aceh dan koalisinya ini memenangkan pemilihan Bupati dan Wakil Bupati dengan memperoleh suara terbanyak yakni 44.356 suara dan unggul jauh dibandingkan oleh pasangan calon yang lain. Meskipun kemenangan ini tidak dapat di klaim sebagai kemenangan partai Aceh karena pasangan ini diusung oleh beberapa partai yang lain seperti partai Demokrat, Partai Gerindra dan partai PKB, namun sekali lagi pengaruh dan keberadaan partai aceh dalam perpolitikan di Nagan Raya semakin jelas terlihat. Hal ini juga memperlihatkan betapa antusiasnya masyarakat Nagan Raya terhadap Partai Aceh 
dibuktikan dengan banyaknya perolehan suara yang diterima oleh pasangan calon usungan dari Partai Aceh ini.

Untuk tingkat Provinsi, kursi parlemen DPRA selalu didominasi oleh keberadaan Partai Aceh di setiap pemilihan anggota legislatif. Fakta yang terjadi dalam realitas politik lokal aceh tingkat Pengaruh mantan kombatan Gerakan Aceh Merdeka (GAM) yang dimotori oleh Partai Lokal salah satu yang menjadi aktualisasi hak politik lewat Partai Aceh (PA) yang selalu menguasai parlemen tingkat Provinsi dengan melihat fakta pada pemilihan umum legislatif 2009-2014, partai Aceh mendapat 33 Kursi dari 69 Kursi, dilanjutkan dengan pemilihan legislatif 2014-2019 Partai Aceh mendapat 29 kursi dari 81 kursi DPRA Provinsi Aceh dan hasil pemilihan legislatif 2019-2024 diperediksi Partai Aceh Juga menguasai parlemen dan mendapat kursi Antara 18-sampai 22 kursi hasil Data Serambi Indonesia, (11 Mei 2019.). Dengan Melihat fenomena diatas tiga priode pemilihan legislalatif di tingkat provinsi 2009-2014-, 2014-2019-dan 2019 sampai dengan 2024, Partai Aceh selalu menguasai parlemen provinsi aceh, akan tetapi yang menjadi permasalahan pengaruh mantan kombatan juga menjadi menurun dalam hal realita perpolitikan di aceh khususnya tingkat parlemen provisni aceh, karena setiap periode pemilihan umum legislatif ada penurunan perolehan kursi yang di dapat oleh Partai Aceh.

Berbeda dengan kontestasi pemilihan Kepala Daerah, pengaruh mantan kombatan GAM dalam memperebutkan kursi Gubernur dan Wakil Gubernur sangat jelas terlihat. Ini dibuktikan dengan selalu unggulnya calon Gubernur dan wakil Gubernur yang memiliki latar belakang sebagai mantan kombatan Gerakan Aceh Merdeka baik yang diusung oleh Partai Aceh maupun oleh partai lokal maupun gubernur incumbent yang juga ikut serta. Pada Pilkada tahun 2007, pasangan Irwandi Yusuf - M. Nazar yang merupakan mantan dari kombatan GAM ini unggul dari pasangan calon gubernur - wakil gubernur lainnya dengan memperoleh suara lebih dari 100.000 suara. Pasangan ini maju memlalui jalur independen dan mendapat dukungan dari para elit mantan kombatan Gerakan Aceh Merdeka yang merupakan awal dari terbentuknya Partai Aceh yang tergabung dalam KPA. Kemudian pada 
Pilkada tahun 2012 yang secara regulasi telah memperbolehkan partai lokal berpartisipasi, setidaknya ada 5 pasangan calon gubernur-wakil gubernur yang berasal dari gabungan partai nasional, partai lokal maupun pasangan independen. Pilkada yang dilaksanakan pada 9 April 2012 itu akhirnya dimenangkan oleh pasangan calon gubernur-wakil gubernur yang diusung oleh Partai Aceh dan berstatus mantan kombatan GAM yaitu dr. Zaini Abdullah - Muzakkir Manaf (ZIKIR). Pasangan ini mendominasi hampir di seluruh wilayah Aceh dengan total perolehan suara 1,327,695 (55,78\%). Kemudian pada Pilkada tahun 2017, perebutan tempat sebagai Gubernur dan Wakil Gubernur semakin seru dengan ikut sertanya kandidatkandidat yang merupakan mantan kombatan GAM Pilkada tahun 2017 memang dimenangkan oleh Irwandi Yusuf dan Nova Iriansyah yang bukan usungan Partai Aceh, namun sekali lagi status Irwandi Yusuf sebagai mantan Gubernur Aceh tahun 2007-2012 yang di dukung oleh para elit GAM yang tergabung dalam KPA (Komisi Peralihan Aceh) saat itu, masih menjadi salah satu alasan kemenangan pasangan ini pada akhirnya memenangkan kompetisi. Dominasi para mantan kombatan GAM yang ikut serta dalam kontestasi pemilihan kepala daerah provinsi Aceh tahun 2012 ini semakin menunjukan betapa besar pengaruh mantan kombatan GAM dalam perpolitikan di Aceh yang tidak dapat dilepaskan lagi dalam kehidupan masyarakat Aceh.

Oleh karena itu berdasarkan paparan diatas, dapat disimpulkan bahwa partisipasi dan keberadaan para mantan kombatan GAM dalam perpolitikan di Aceh tidak dapat dipungkiri lagi pengaruhnya baik secara langsung maupun tidak langsung dalam politik praktis. Hal disebabkan oleh tingginya kemenangan para mantan kombatan GAM dalam pemilu yang mengantarkan mereka menempati posisi strategis di pemerintahan yang merupakan dasar dari perencanaan, pengelolaan dan pelaksanaan upaya-upaya untuk mensejahterakan rakyat Aceh. 


\section{Indikator Yang Digunakan Mantan Kombatan GAM Untuk Masuk Dalam Perpolitikan Aceh}

Dalam perjalanan perpolitikan Aceh pada era Otonomi Khusus ini tidak terlepas dari peran para mantan kombatan GAM dalam memperjuangkan hak-hak dan kepentingan rakyat Aceh sehingga diberikannya kekhususan bagi Aceh yag tertuang dalam Undang-Undang No. 11 Tahun 2006 tentang Pemerintah Aceh, dimana hal ini juga memberikan peluang bagi para mantan kombatan GAM ikut serta dalam perpolitikan di Aceh. Dalam penelitian ini ditemukan fakta-fakta terkait indikator yang digunakan oleh para mantan kombatan GAM untuk ikut serat dalam perpolitikan di Aceh :

\section{Partai Politik Lokal}

Sebagaimana dalam UU No. 11 Tahun 2006 BAB XI tentang Partai Politik Lokal dan Qanun Aceh No. 3 Tahun 2008 tentang Partai Politik Lokal Peserta Pemilihan Umum Anggota Dewan Perwakilan Rakyat Aceh dan Dewan Perwakilan Rakyat Kabupaten/Kota, salah satu cara mantan kombatan GAM masuk dalam politik praktis adalah dengan membentuk Partai Politik Lokal. Pada awal mula pasca konflik, para mantan kombatan GAM tergabung dalam Komite Peralihan Aceh (KPA). KPA ini yang kemudian menjadi sebuah wadah yang merupakan cikal bakal terbentuknya Partai Aceh yang saat ini merupakan salah satu Partai Lokal yang sangat berpengaruh besar dalam perpolitikan di Aceh.

\section{> Ikut Pemilukada dan Pemilu Legislatif}

Setelah membentuk Partai Politik, untuk masuk dalam sistem perpolitikan di Aceh langkah selanjutnya yang diambil oleh para mantan kombatan GAM yaitu ikut berkontestasi dalam pemilhan umum baik itu pemilihan kepala daerah maupun dalam pemilihan anggota Dewan Perwakilan Rakyat baik tingkat Provinsi maupun Kabupaten/Kota. Hal ini sangat penting dikarenakan pusat kontrol dalam segala aspek yang ada di Aceh terletak pada komponen tersebut. Oleh karenanya, ikut dalam pemilukada dan pemilu legislatif merupakan jalan wajib yang harus ditempuh untuk masuk dalam sistem perpolitikan di Aceh di masa Otonomi Khusus ini. 


\section{Basis Yang Luas}

Untuk mendukung keikutsertaan mantan kombatan GAM dalam perpolitikan di Aceh, tentu diperlukan basis atau massa yang besar. Namun hal itu bukanlah sesuatu yang sulit dikarenakan para mantan kombatan GAM memiliki massa yang terkoneksi dengan baik dari pusat Aceh hingga ke daerah Kabupaten/Kota maupun desa yang ada di Aceh. Dikarenakan hal tersebut, Partai Aceh yang merupakan poros para mantan kombatan GAM tidak terlalu sulit dalam berkampanye dikarenakan sudah ada massa yang dari dulu terbentuk dan terorganisir dengan baik. Hal ini yang kemudian menjadi salah satu kunci bagi para mantan kombatan GAM untuk ikut serta dalam perpolitikan di tanah rencong Aceh ini. Untuk hal bersaing dalam memperebutkan suara rakyat, mantan kombatan GAM sama halnya dengan peserta pemilu lainnya yakni dengan pendekatan kepada masyarakat, menjalin hubungan yang sinkron, merangkul dan tanggung jawab. Namun yang menjadi kelebihannya adalah dimana mantan kombatan GAM ini dikenal dengan kelompok perjuangan yang sehingga menjadi salah satu nilai lebih yang tidak dimiliki peserta pemilu lainnya yang bukan mantan kombatan GAM.

\section{$>$ Melanjutkan Pendidikan}

Disadari oleh para mantan kombatan GAM, bahwa pendidikan menjadi salah satu hal yang penting dalam memasuki sistem perpolitikan di Aceh. Oleh karena itu banyak mantan kombatan GAM seiring berjalannya waktu melanjutkan pendidikan mereka ke jenjang yang lebih tinggi. Dengan adanya peningkatan mutu pendidikan yang ditempuh oleh mantan kombatan GAM menjadikan kredibilitas dan kapasitas mereka dalam perpolitikan semakin tinggi dan dapat mempengaruhi suara yang diperoleh para mantan kombatan GAM dalam pemilihan umum baik kepala daerah maupun pemilihan anggota parlemenen baik tingkat provinsi maupun kabupaten/kota yang ada di Aceh.

Indikator-indikator yang digunakan oleh para mantan kombatan GAM (Partai Aceh) untuk memasuki sistem perpolitikan di Aceh pada dasarnya tidak jauh berbeda dengan cara-cara yang digunakan oleh para pelaku politik praktis lainnya. Hanya saja 
keunggulan yang dimiliki oleh para mantan kombatan GAM dalam hal meraup suara rakyat yaitu terletak pada anggapan masyarakat bahwa mereka adalah pejuang hakhak rakyat Aceh dan hal itu masih terus berlangsung hingga saat ini yang kemudian memudahkan mereka masuk dalam sistem perpolitikan Aceh hingga saat ini.

\section{SIMPULAN}

Fakta dilapangan menunjukan bahwa pengaruh mantan kombatan GAM dalam perpolitikan di Aceh sangat besar, dibuktikan dengan mendominasinya Partai Aceh (bentukan elit mantan kombatan GAM) dalam pemilihan umum baik kepala daerah maupun parlemen baik ditingkat Provinsi maupun Kabupaten/Kota. Hal ini diperkuat dengan idikator-indikator yang betul-betul penting dalam meraup suara rakyat yang memperkokoh kedudukan mereka dalam perpolitikan di Aceh. Namun tidak dapat dipungkiri juga bahwa ada penurunan perolehan suara maupun kursi yang didapatkan oleh Partai Aceh yang disebabkan oleh berbagai faktor seperti perkembangan zaman, semakin terbukanya pemikiran masyarakat dan lain sebaginya yang mempengaruhi masyarakat dalam menentukan pilihannya dalam setiap pemilihan umum yang dilakukan.

\section{REFERENSI}

Afdhal. 2013. Analisis Strategi Partai Aceh Dalam Pemilukada Aceh 2012. Jurnal POLITEIA FISIP USU. Volume 6, ISSN : 0216-9290.

Agung Djojosoekarto, dkk., 2008, Kebijakan Otonomi Khusus di Indonesia, Pembelajaran dari Kasus Aceh, Papua, Jakarta, dan Yogyakarta, Kemitraan, Jakarta, hlm. 10

Arikunto, Suharsimi. 2001. Strategi Belajar Mengajar. Jakarta: Universitas Terbuka. Hlm. 54

Arikunto, Suharsimi. 2006. Prosedur Penelitian Suatu Pendekatan Praktik. Jakarta: Rineka Cipta.

Burhan Bungin. 2001. Metode Penelitian Kualitatif. Jakarta: PT Rajagrafindo Persada.

Hadi, Kisno. 2010. Satu Dasawarsa Relasi Politik Lokal Dan Nasional Dalam Konteks Otonomi Daerah. Jurnal Program Studi Magister Ilmu Politik Universitas Diponegoro Volume I, Nomor 2, Oktober 2010. 
Jacobus Perviddya Solossa, 2006, Otonomi Khusus Papua, Mengangkat Martabat Rakyat Papua di Dalam NKRI, Pustaka Sinar Harapan, Jakarta, hlm. 53.KIP Aceh Barat dan Nagan Raya

Malahayati. 2015. Otonomi Khusus dalam Sistem Pemerintahan Indonesia. hlm. 21

Mujibussalim. Akbar, Feisal. 2017. Eksistensi Partai Politik Lokal Di Aceh. Jurnal Ilmiah Mahasiswa FISIP Unsyiah Volume 2, Nomor 2: 230-247 Juli 2017.

Pasal 18B ayat (1) UUDNRI 1945 menyatakan bahwa "Negara menagkui dan menghormati satuan-satuan pemerintahan daerah yang bersifat khusus atau bersifat istimewa yang diatur dengan undangundang."

Undang-Undang No. 11 Tahun 2006 tentang Pemerintah Aceh.

Qanun Aceh No. 3 Tahun 2008 Tentang Partai Politik Lokal Peserta Umum Anggota Dewan Perwakilan Rakyat Aceh dan Dewan Perwakilan Rakyat Kabupaten/Kota.

Zainal, Suadi. 2016. "Transformasi Konflik Aceh dan Relasi Sosial - Politik di Era Desentralisasi”. MASYARAKAT: Jurnal Sosiologi 21 (1): 81-108.

Zuhri, Fajrul. Khairulyadi. 2017. Reintegrasi Mantan Kombatan Gerakan Aceh Merdeka. Jurnal Ilmiah Mahasiswa FISIP Unsyiah Volume 1, Nomor 1, Januari 2017. http://beritakini.co/news/25-caleg-yang-lolos-ke-dprk-naganraya/index.html di akses tanggal 25 Mei 2019 pukul 10.43 WIB

https://tekon.kompas.com/read/2012/07/04/04112756/partai.aceh.unggul.di.tiga.kabu paten di akses tanggal 25 Mei 2019 pukul 10.55 WIB.

https://www.google.com/amp/aceh.tribunnews.com/amp/2014/04/10/tingkat-dprkgolkar-masih-unggul-di-nagan-raya di akases tanggal 25 Mei 2019 pukul 11.04 WIB https://www.diliputnews.com/read/27523/25-anggota-dprk-nagan-raya-dilantik.html diakses tanggal 25 Mei 2019 pukul 11.06 WIB.

https://www.google.com/amp/aceh.tribunnews.com/amp/2016/07/19/pa-deklarasijadin-sebagai-capup-cawabup-nagan-raya di akses tanggal 25 Mei 2019 pukul 18.26 WIB.

https://www.kompasiana.com/haramli/57071aa4ee927353055ab53f/cinta-segitigagam-di-pilkada-aceh di akses tanggal 26 Mei 2019 pukul 14.53 WIB. 